\title{
爲蘇聯先進科學的歴史性成就而歡呼
}

社諭

葆聯第一個原子能工業電力站已於 6 月 27 日 開始發電了, 這是人類第一次將原子能㗹用於和 平工業, 造是一個偉大事業的開始。這個事業將 如歴史上曾經發生過的, 和原始人學會了用火,

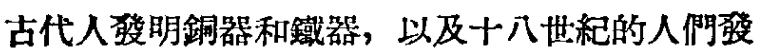
明蒸汽機那樣, 使整個人類的生活墢生極深刻的 化。原子能開始隹用於和平工業, 意味着人類 已開始有可能無限地控制自然的自發力量; 由 此, 原子能將成篇人類未來繁榮幸福生活的巨主大 泉源。但人類發現原子能和掌握原子能的過程不 是一個和平順利的過程, 它是人類向自然進行長 期椱雜的网争過程, 同時也反胎著人類社會內部

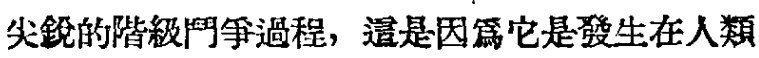
歴史上最後一個鈢㓩階級走向死亡的時代。歷史 上從來没有一個科學和技術上的問題, 像原子能 問題這樣, 在經游、政治和思想上引起邆樣直接 而琵重的影響。

大家還記得，當1939年墢現鋾原子核分裂現 象時, 整個科學界都篇銷核分裂所放出的巨大能

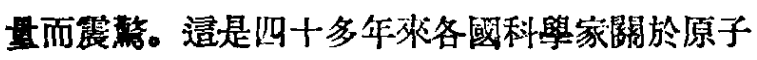
的研究所獲得的最偉大的成就, 人們把它與賞初 法拉第發現笔磁感㮣和㑊茲墢現電磁波相比。無

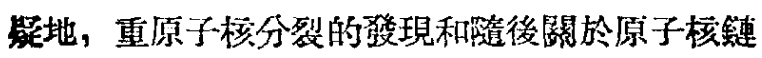
反應的研究, 開閵了一個原子能地紀, 帶來人類幸 酾的無限的希望，人們興鹪地以百萬倍於現有的 数量來量計未來的能源。但十分不幸的，原子能 的㙁際隹用, 最初却是以原子彈的形式出現的;

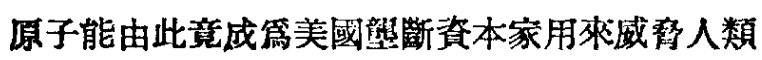
安全、向人民淮行誂作和掠䆶的工具。

美國熊斷資本家利用第二次大戰期間美國沟 有受到戰爭的破填, 和綮洲資本主義國家科學家 的大批流亡到美國的機會，他們偷偷地謷成原子 彈, 並在戰争即要最後結束的時候使用了它。第
二次大戰剛結束, 美國就以原子帝國主的狒 嚓面目出現於世界。美國好戰分子手持原子彈, 向世界叫綮着原子戰爭, 瘋狂地發動“冾戰”，製 造新的戰爭威骨。他們以一百億美元的投資 $(19$ 54 -1955年通一年度預算即有 24 億 2 千 5 百萬美 元)和 20 萬的工作人員來從事原子軍備。於原 子能應用於和平工業, 他們不但不感興趣, 反而

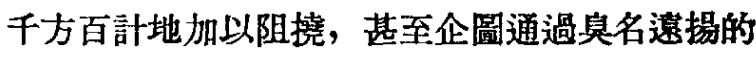
“巴魯區計劃”，秝䄳横地限制其他國家（首先是

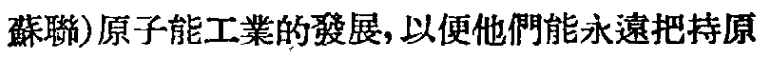

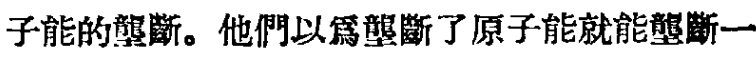
切。在他們統治的國內，他門承襲着希特勤的一 套, 迫害正直的科楽家（如所周知, 他們公然殺 害羅森堡夫媂, 迫害年菊的要因斯坦, 甚至迫客 最初寥加領導原子彈彆造工作的奥本海謨)，扼殺

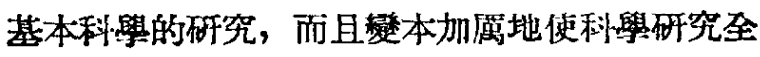

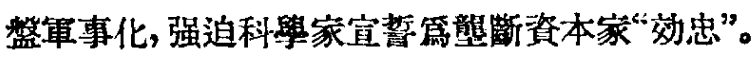
他們遠經常製造原子彈的恐怖，來珠唬兒童，欺 駢本國人民，使他們造成緊張的精神枵態。八、 九年來，美國蟹斷資本家就這檬玩崝着原子能， 他們靠着原子叱詐, 整造國際緊張局勞, 由此來 搐取最大限度的利潤。本來可篇人類創造無限幸 稫的原子能，落在美國筮斷資本家的手中，反而 成篇一個㲘在人類頭上的㩆大的危險。

但是歷史是不回頭的，已經看見了共库主我 勝利的人民是路不退的。原子彈固然給世界和体 與人類安全帶承威韋，同時它也帶來了全世界人

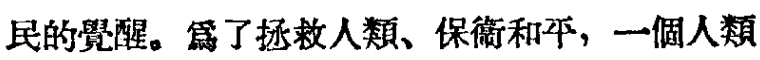
歷史上從未有過的巨大規模的運動在所有的國家 （包括在美國）裹開展了。有五億的人民在斯德

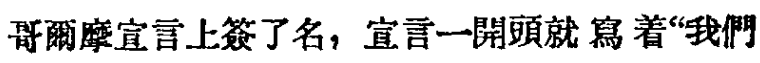
要求無條件地禁用原子武器”! 成千成萬個資本 主義國家的科學家在正義和罪惡的面前块擇了 


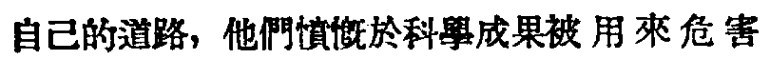
人類，齊㹂地高呼着要“琭救科堅”。道個逐救人

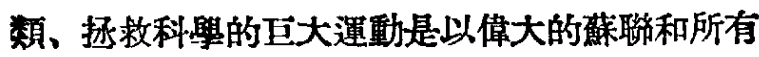
人民民主國家篇支柱的，因此它是不可戰勝的。 特别是由於绿联的强大和它的堅定不移的和平政 策, 由於葆聯的原子工業的迅速祋展, 終於使美 國原子誰詐政策徹底破產。

蘇聯始終如一地主張無條件禁用原子武器, 主張把原子能用於和平事業。美國好戰分子䆓把 蒜样的正義主張看作是由於蘇聯沟有原子彈; 最 初他阿瞥算着蘇聯在 1952 年甚至 1955 年以前不

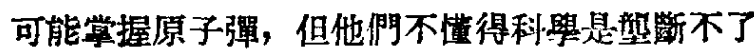
的, 无其是社會主義先進科學發展的警人速度更 不是他們所能想像的。罱了保衡社會主義祖國和 世界和平, 第了制等美國的原子驡斷和解除人類 遭受原子戰爭的威育, 但最根本的, 還是篇了把原 子能用於和平目的, 篇增加能會剘富和第人民謀 幸福, 蘇称迅速地發展了原子工業。由於蘇聯人民

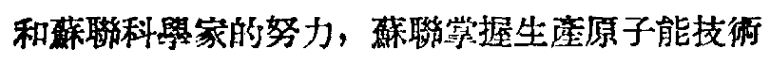
的速度比美國快, 蘇聯在原子科學研究上也已超 過了美國, 而居世界第一位。事筫上, 菻聯在 1947 年就已掌握了原子彈的彆造技術, 隨後還陸縜掌 握了经彈等各種原子武器的生産方法; 同時, 蘇聯 利罗家篇原子能用於共產主義建設作了巨大的努 力. 今天, 以薮聯篇首的世界和平民主力量已經 涬到如此强大的程度, 它已有可能使仗着原子彈 第“賽力”後盾的侵略集国認識到: 倘若他們胆敢 冒險使用原子武器的話, 那末, 頻被原子能的咸 力所摧毁的不是别的, 而是他們自己和整個篦朽 的資本主義制度。道說明了蘇聯不僅在道義上一 值主張禁用原子武器, 而且用自己的資際行動來 促使逜個主張的需現。

强聮先進科學在保衡世界和平的事業中完成 成了一系列的重大成就後, 現在又進而顬現了十 五年來世界各個科學家所共同懹抱着的偉 大理 想. 㯰就是最近蘇跏政府宣佈的, 独聨已成功地

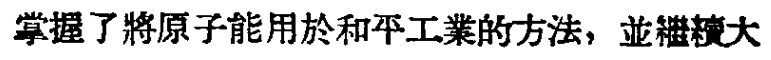

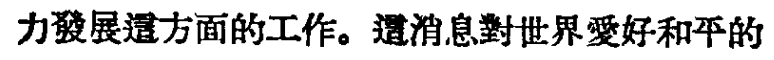
人民是一個極大的鼓舞，邆消息就等於宣佈原子 能世紀的员正到來, 它意味着一個巨大的技得革

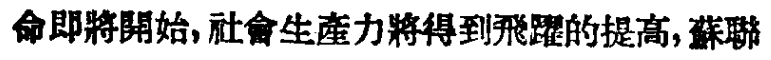
的共库主蒨建設將加速前進, 世界和平力量將無
限垛强。原子能在美國熋斷資本家的手中, 就是致 人類的籊重威育和罪惡的詐詐, 當它轉入到以蘇 聯黨首的人民民主陳營的手中, 就立刻成篇世界 和平的保障和人類幸福生活的偉大創造力量了。

原子能篇戰争還是篇和平服務的問題, 是戰

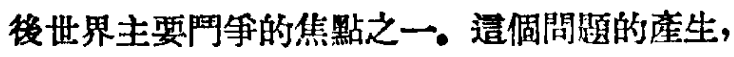

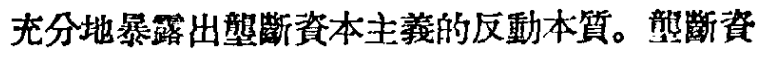
本主義對待原子能，和資本主義在初期對蒸汽機 的發明探取熱烈鹳迎的態度完圣相反。事貿上， 原子能所帶來的新的生產力, 不是资本主義葆世 界所能容納得下的, 它將給資本主義帶㲻新的內 在矛盾與危機。

垂死的資本主義不僅對原子能的合理應用探

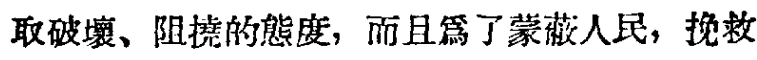
自己, 在原子科學理論研究上, 它造一贯琶清地 利用人們賟不熟恐的物理學上的新成就來宣傳宗 孜, 散作唯心主義的思想, 不㜔科學在正確的道

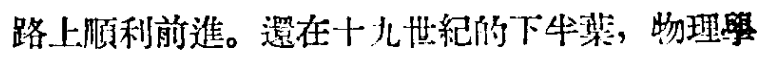
家從深入熱力學的研究提出分子的理输時, 以馬 赫篇代表的主觀唯心論者會顾固地反對邆理諭, 他們以人類不能直接感學到分子和原子第藉口， “否認”分子和原子的存在。在十九世紀和二十世 紀交替的十年中間，由於放射性現像等一速串的 重要物理現象的發現，整個物理煘開始了一個以 研究原子和“基本”粒子篇中心的新紀元，但馬赫 的垖隨者却堿着这是物理學的“危機”，他們把人 類對物質粠造本質的新認識說成是“物岓消隇 了”, 造成了當時物理學家思想上很大的混微。當

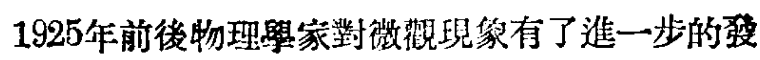
現時, 主觀唯心論者、神秘主義者文來一次猖狂 的進攻，他們叫量着用“自由意志”來代替因果律， 用感學來代替客觀的存在。一次物理罢的“危機” 又出現了，這次“危機”是泛溜得空前噘重的，使很 多資本主義國家的物理學家在研究工作的指導思

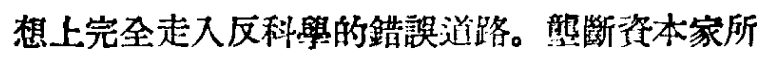

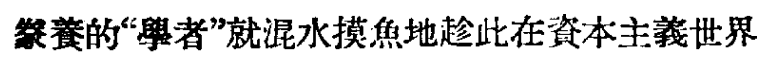
的整個思想領域內製造出一一個新的反動潮流, 他 們宣稱宗敉已在原子世界異找到“科學根撜”，科 學應作䉆宗的一個部門，或者科學應淁位給宗

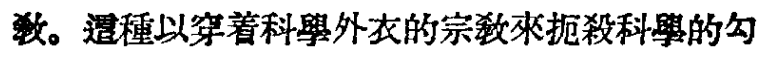
當, 本質上和封建統治者禁止哥白尼的學說完全 一檬; 但歷史告訴我們, 由哥白尼的學說所引起: 
的鬥爭，是以企圖扼殺科眾的封建統治自身的堿 亡陑宣告結束的。

偉大的列寧在二十世紀初就密切地注意原子 科學的生長, 在和原子科學研究領域內唯心論的 网等中，他完成了極共重要的工作。以馬克思列 主義武裝起來的蘇聯科罣家，在蘇聯共產黨中 央和斯大林的敎䢘下，繼承着列寧的工作，和原 子科學中用各色各樣外衣化裝着的唯心論與宗敉 迷信蕉行不疲佼的非爭; 這樣, 不但保登了䔻聯 原子科學的迅逢發展，並且能不斷以原子科學理 論研究的新成果來哣富馬克思列寧主義的哲學。

牛㑑多世紀來, 人類發現原子能和学握原子 能的全部閏等譙明了：人類對於自然規律進一步 的認識與掌拉，無諭在理論上或者在實蹑上都日 谷接近着共産主義。

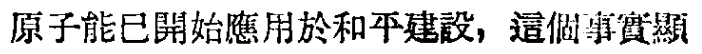

示出科學和吩會主義相結合所産生的無敵力量, 預示着共產主義事業的完全勝利3 同時, 它也等 於給原子誂詐者宣制死刑，預示着原子帝國主数 的覆诚。

正在向融會主義大道上前進的中國科學工作

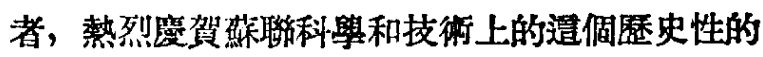
成就。由於蘇聯原子能生座上所已取得的偉大成 就，我倐可以預見到，中國和其他人民民主國家 將有更好的條件來加速地完成缡會主義建設的任 務。我們索心感謝蘇聯人民和蘇聯科燢家第人類

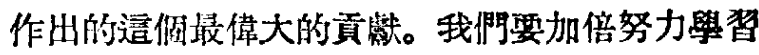

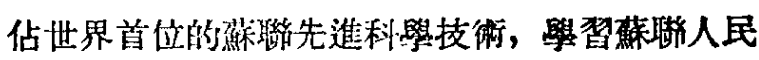
和蘇聯科學家在共虐主義建設和保衞世界和本事 業中堅持不懈的梐爭精神, 篇祖國的偉大建設和 世界的持久和平貢裙出力量!

\section{更 正}

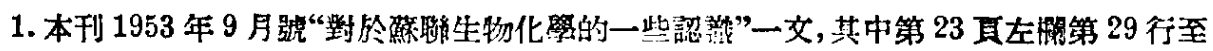

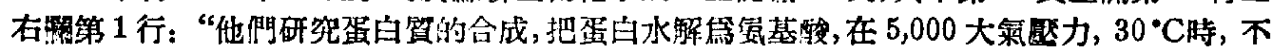

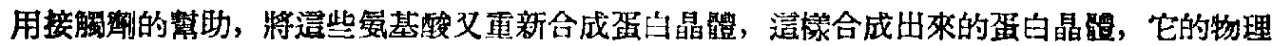

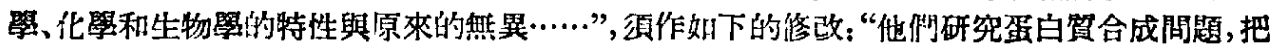

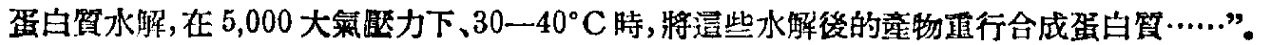

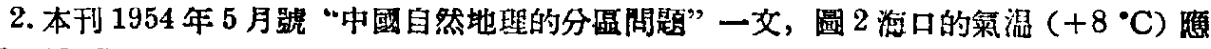
政丽 $\left(18^{\circ} \mathrm{C}\right)$ 。

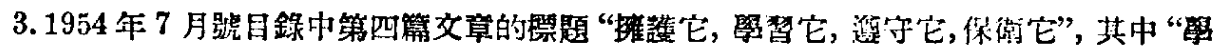

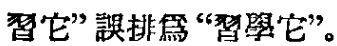

4. 1954 年 7 月號 “三十年來等路在澌量學上的成就”一文, 47 頁右橍第 4 行，“過去我

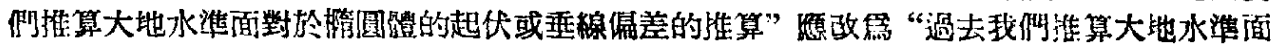

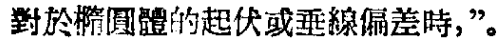

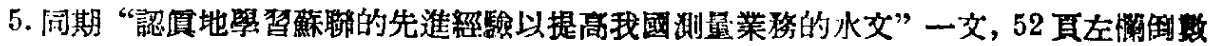

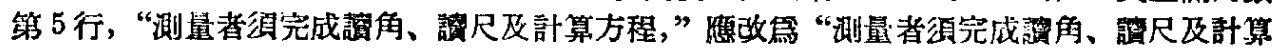

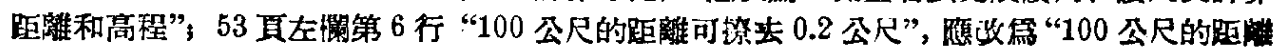
可挴去 0.2 公尺”. 